[DOI: 10.24214/jecet.A.8.1.11022]

Jaurnal of Environmental Science, Computer Science and Engineering \& Technology

An International Peer Review E-3 Journal of Sciences and Technology

Available online at www.jecet.org

Section A: Environmental Science

Research Article

\title{
Commercial Fish Catch as an Index of Lakes Eutrophication in Egypt
}

\author{
Maiyza, Sh. I. and El-Caryony, I. A. \\ National Institute of Oceanography and Fisheries (NIOF),Egypt
}

Received: 26 December 2018; Revised: 02 February 2019; Accepted: 12 February 2019

\begin{abstract}
The study is an attempt to identify the location of Egyptian Northern Mediterranean Delta Lakes in relation to Vollenweider classification of lakes from oligotrophy to polytrophy in the course of eutrophication process. Time series approach has been used to achieve the aim of the study and to predict future catches from these lakes. It was found that Egyptian Northern Delta Lakes can be considered in the 5th stage of Vollenweider model.
\end{abstract}

Keywords: Eutrophy, ecosystem, Time series, Fishery management, Pollution, Egyptian Mediterranean Lakes

\section{INTRODUCTION}

Study of limnological characteristics is dealing mainly with the problem of lakes eutrophication. They aim to define the trophic degree in lakes and review the broad scale of lake classification from oligotrophy to polytrophic ${ }^{1}$. Such studies are of high theoretical and cognitive value. However, problems of how to: -study the dynamics of eutrophication process, -estimate its rates with time, and predict changes in lake ecosystem in the course of eutrophication process.

So, eutrophication is an important process and requires further studies to define the different degrees (of eutrophication). Recently the rate of change in lakes ecosystem is so high. It should be mentioned that due to rapid eutrophication process, oligotrophic lakes are practically disappeared ${ }^{1}$. Anderson, ${ }^{2}$ used the statistical and arithmetical methods of time series approach to draw fishery management and its economics. He concluded that every phenomenon has a trend with specific features. So comparing trends (two or more) of different phenomena or the same phenomenon but in different place or time could accomplish the aim of the study. 
This study is an attempt to identify the classification of Egyptian Northern Delta Lakes (Mariut, Edku, Burullus and Manzala) from the Vollenweider classification point of view. Prediction of future catch rates from these lakes, which contribute about $13.9 \%$ of Egyptian lakes area ${ }^{3}$, is also a goal of the present study.

\section{METHODS AND DISCUSSION}

The material consisted of the fisheries official data, extracted from the Central Agency of Public Mobilization and Statistics (CAPMS) ${ }^{4}$ in the period (1991-1994), General Authority for Fish Resources Development (GAFRD) ${ }^{5}$ in the period (1995-2013), and Seasonal report ${ }^{6}$ (2012-2013) of Environmental monitoring program for northern lakes in Egypt. In the present study the authors will mention the lakes in the order of GAFRD; i.e. Manzala, Mariut, Burullus and Edku,

Data analysis in the present study depends on statistical and arithmetical methods:

- time-series approach,

- coefficient of variation,

- percentage, marginal increments, and

- Parabolic curve trend.

\section{Relative Importance of Northern Delta Lakes}

There are many fish resources in Egypt such as natural resources (seas, lakes, Nile river and its branches), and Aquaculture. Lake fisheries in Egypt are consists of three main sources, Northern Delta Lakes, inland lakes, and coastal lagoons.

1.1 . Relative Importance of Total Area: The Egyptian Northern Delta Lakes or Egyptian Northern Mediterranean Delta Lakes considered the most important lakes of Egyptian lakes fisheries, and they consist of four lakes (Mariut, Edku, Burullus and Manzala; from west to east), Figure (1).

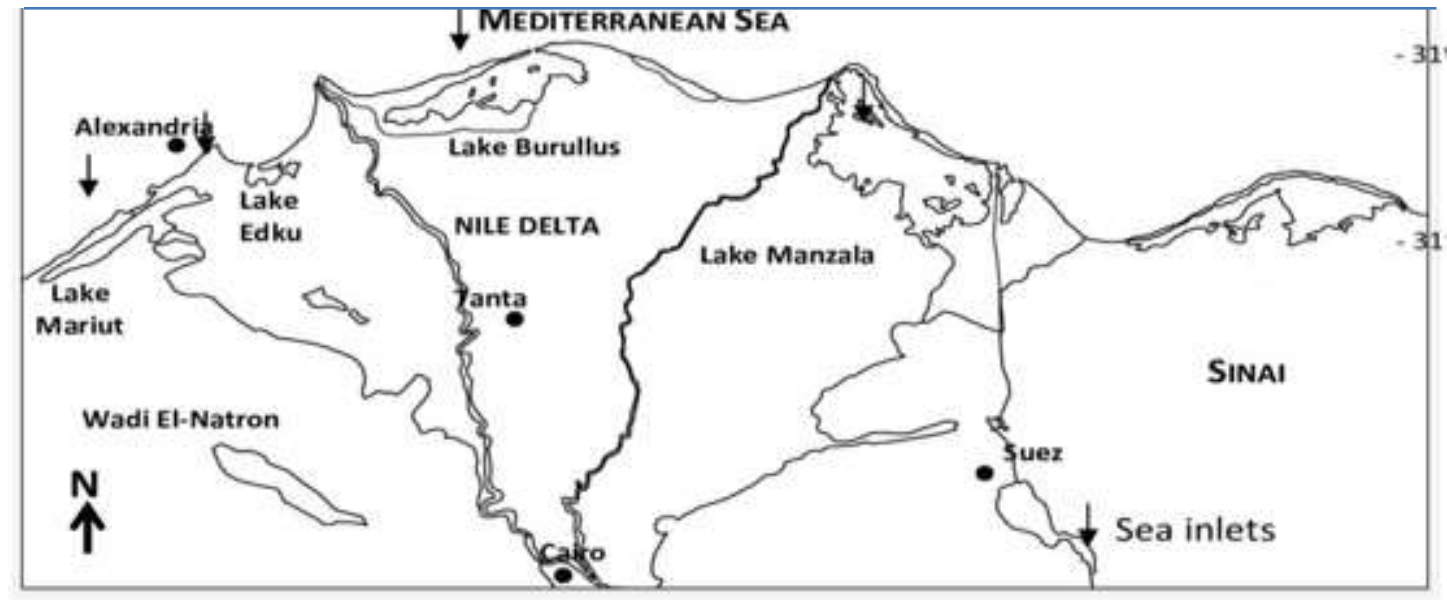

Figure (1): Egyptian Mediterranean Delta Lakes.

These Lakes are considered as shoreline lakes, which cut off from the sea by the creation of spots caused by sediment accretion due to longshore sediment movement ${ }^{7}$. Table (1) shows that the total area of the lakes under study are about $252 * 10^{3}$ acre representing about $13.9 \%$ of Egyptian lakes area, $1.9 \%$ of natural fisheries area, and $1.8 \%$ of Egyptian fisheries area. 
Table (1): Relative Importance of Individual and Total Area of Northern Delta Lakes of Egypt during (1991-2013).

\begin{tabular}{|c|c|c|c|c|c|}
\hline lake & $\begin{array}{l}\text { Northern } \\
\text { Delta } \\
\text { Lakes Area } \\
\left(\text { acre }^{*} \mathbf{1 0}^{3}\right)\end{array}$ & $\begin{array}{c}\text { \% from } \\
\text { Northern } \\
\text { Delta Lakes } \\
\text { Area }\end{array}$ & $\begin{array}{c}\text { \% from } \\
\text { Egyptian } \\
\text { Lakes } \\
\text { Area }\end{array}$ & $\begin{array}{c}\text { \% from } \\
\text { Natural } \\
\text { fisheries } \\
\text { Area }\end{array}$ & $\begin{array}{c}\text { \% from } \\
\text { Egyptian } \\
\text { fisheries } \\
\text { Area }\end{array}$ \\
\hline Manzala & 120 & 47.6 & 6.6 & 0.91 & 0.86 \\
\hline Mariut & 15 & 6.0 & 0.83 & 0.114 & 0.11 \\
\hline Burullus & 103 & 40.9 & 5.7 & 0.78 & 0.74 \\
\hline Edku & 14 & 5.5 & 0.77 & 0.106 & 0.10 \\
\hline $\begin{array}{l}\text { Northern Delta } \\
\text { Lakes Area }\end{array}$ & 252 & 100.0 & 13.9 & 1.910 & 1.81 \\
\hline $\begin{array}{c}\text { Egyptian Lakes } \\
\text { Area }\end{array}$ & 1818 & - & 100.0 & - & - \\
\hline $\begin{array}{c}\text { Natural fisheries } \\
\text { Area }\end{array}$ & 13205 & - & - & 100.0 & - \\
\hline $\begin{array}{c}\text { Egyptian } \\
\text { fisheries Area }\end{array}$ & 13905 & - & - & - & 100.0 \\
\hline
\end{tabular}

Source: collected from $\square$ Maiyza, I.SH.(2015), An Economic study of Fish Production In Alexandria Mediterranean Sea Fisheries,Ph.D., Faculty of Agriculture, Alexandria University, Egypt.

1.2. Relative Importance of Fish catch:The total fish catch from Northern Delta Lakes in the period of the study is about $127.1 * 10^{3}$ ton annually, which represent about $73.3 \%, 34.5 \%$, and $15.8 \%$ from Egyptian lakes Production, Natural fisheries production, and total Egyptian fish production consequently - Table (2).

Table (2): Relative Importance of Fish catch from Northern Delta Lakes of Egypt during (1991-2013).

\begin{tabular}{|c|c|c|c|c|c|c|}
\hline lake & $\begin{array}{c}\text { Average } \\
\text { Production } \\
\left(\text { tons }^{*} \mathbf{1 0}^{3}\right)\end{array}$ & $\begin{array}{c}\% \text { from } \\
\text { Northern } \\
\text { Delta } \\
\text { Lakes } \\
\text { production }\end{array}$ & $\begin{array}{l}\text { \% from } \\
\text { Egyptian } \\
\text { Lakes } \\
\text { production }\end{array}$ & $\begin{array}{c}\% \text { from } \\
\text { Natural } \\
\text { fisheries } \\
\text { production }\end{array}$ & $\begin{array}{c}\% \text { from } \\
\text { total Egyptian } \\
\text { fish } \\
\text { production }\end{array}$ & $\begin{array}{c}\text { Coefficient } \\
\text { of Variation } \\
\text { (C.V \% * }\end{array}$ \\
\hline Manzala & 59.0 & 46.4 & 34.0 & 16.0 & 7.3 & 19.8 \\
\hline Mariut & 4.9 & 3.9 & 2.8 & 1.3 & 0.6 & 25.9 \\
\hline Burullus & 54.7 & 43.0 & 31.5 & 14.9 & 6.8 & 7.2 \\
\hline Edku & 8.5 & 6.7 & 5.0 & 2.3 & 1.1 & 19.0 \\
\hline $\begin{array}{c}\text { Northern Delta } \\
\text { Lakes }\end{array}$ & 127.1 & 100.0 & 73.3 & 34.5 & 15.8 & - \\
\hline $\begin{array}{l}\text { Egyptian } \\
\text { Lakes }\end{array}$ & 173.4 & - & 100.0 & - & - & - \\
\hline $\begin{array}{l}\text { Natural } \\
\text { fisheries }\end{array}$ & 367.8 & - & - & 100.0 & - & - \\
\hline $\begin{array}{l}\text { Egyptian fish } \\
\text { production }\end{array}$ & 803.0 & - & - & - & 100.0 & - \\
\hline
\end{tabular}

$*=\left(\square \square Y^{2}-(\square Y)^{2} / n \square / n\right)^{1 / 2} / \mathbf{Y} \times 100$.

Source: collected from;1-CAPMAS - Yearbook of Fishery statistics- (1991-1994) Cairo, Egypt, 2016. 2-

GAFRD - Yearbook of Fishery statistics- (1995-2013) - Cairo, Egypt, 2016. 


\section{Evolution of Fish catches of Northern Delta Lakes}

2.1. Fish catch in Manzala Lake: Manzala lake is the biggest lake according to its area among Northern Delta Lakes. Its fish catch oscillated from year to year with an annual average of about $59.0^{*} 10^{3}$ ton during the period of study (1991-2013). The cubic curve was estimated to represent its best fish catch trend in this lake.

$\hat{\mathrm{Y}} 1=40.771+10.543 \mathrm{X}-1.171 \mathrm{X}^{2}+0.034 \mathrm{X}^{3}$

$(4.429)^{* *}(3.242) * *(-3.761) * *(3.955) * * \mathbf{R}=0.693 \quad \mathbf{R}^{2}=\mathbf{0 . 4 8 0} \quad \mathbf{F}=5.853 * *$

Where:

$\hat{\mathbf{Y}} \mathbf{1}$ : Estimated fish catch (thousand tons).

$\mathbf{X}$ : Time throw the period (1991-2013).

$(\ldots)^{* *}$ : T test is significant approximately 0.01 .

Extremes of the parabola.

$\mathrm{d} \hat{\mathrm{Y}} 1 / \mathrm{dX}=10.543-2.342 \mathrm{X}+0.102 \mathrm{X}^{2}=0$

$0.102 X^{2}-2.34 X+10.54=0 \quad(0.10 X-1.76)(X-6)=0$

$X=17 \quad, \quad X=6$ Maximum fish catch at $X=6$, i.e. 1996.

Minimum fish catch at $\mathrm{X}=17$, i.e. 2007.

From the above equations representing Manzala Lake, it is clear that: fish catch in this lake reached a maximum in 1996, and a minimum in year 2007- Figure (2), the coefficient of variation (c.v. \%) of Manzala fish catch was about $19.8 \%$ - table (2).

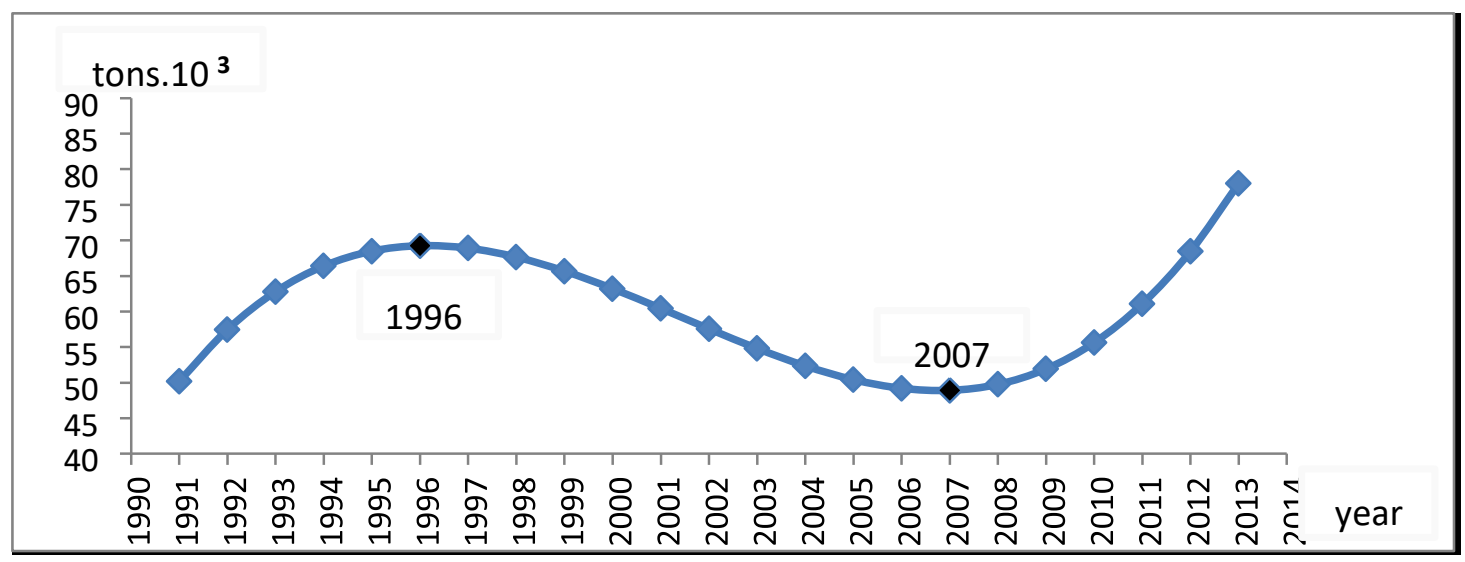

Figure (2): Trend of fish catch in Manzala Lake during (1991-2013)

2.2. Fish catch in Mariut Lake :As shown in table (2), fish catch in Mariut Lake oscillated from year to year with an annual average about $4.9 * 10^{3}$ ton during the period of study, and its value of coefficient of variation (c.v. $\%=25.9 \%$ ). Cubic curve represent best fish catch trend. The fish catch extremes (maximum and minimum values) are in years $1999 \& 2011$ respectively as shown in Figure (3)
$\hat{\mathrm{Y}} 2=0.923+1.067 \mathrm{X}-0.088 \mathrm{X}^{2}+0.002 \mathrm{X}^{3}$
$(1.470)$
$(4.812) * *$
$(-4.160) * *$
$(4.040) * * \mathrm{R}=0.892$
$\mathrm{R}^{2}=0.795$ $\mathrm{F}=24.601 * *$ 


\section{Where:}

$\hat{\mathbf{Y}} 2$ : Estimated fish catch (thousand tons).

$\mathbf{X}$ : Time throw the period (1991-2013).

(...): T test is not significant.

$(\ldots)^{* *}$ : T test is significant approximately 0.01 .

\section{Extremes of the parabola.}

$d \hat{Y} 2 / d X=1.067-0.176 X+0.006 X^{2}=0$

$$
\begin{array}{r}
0.006 \mathrm{X}^{2}-0.176 \mathrm{X}+1.067=0 \\
(0.006 \mathrm{X}-0.126)(\mathrm{X}-8.5)=0 \\
X=21 \quad, \quad X=9
\end{array}
$$

Maximum fish catch when $X=9$, in 1999.

Minimum fish catch when $\mathrm{X}=21$, in 2011.

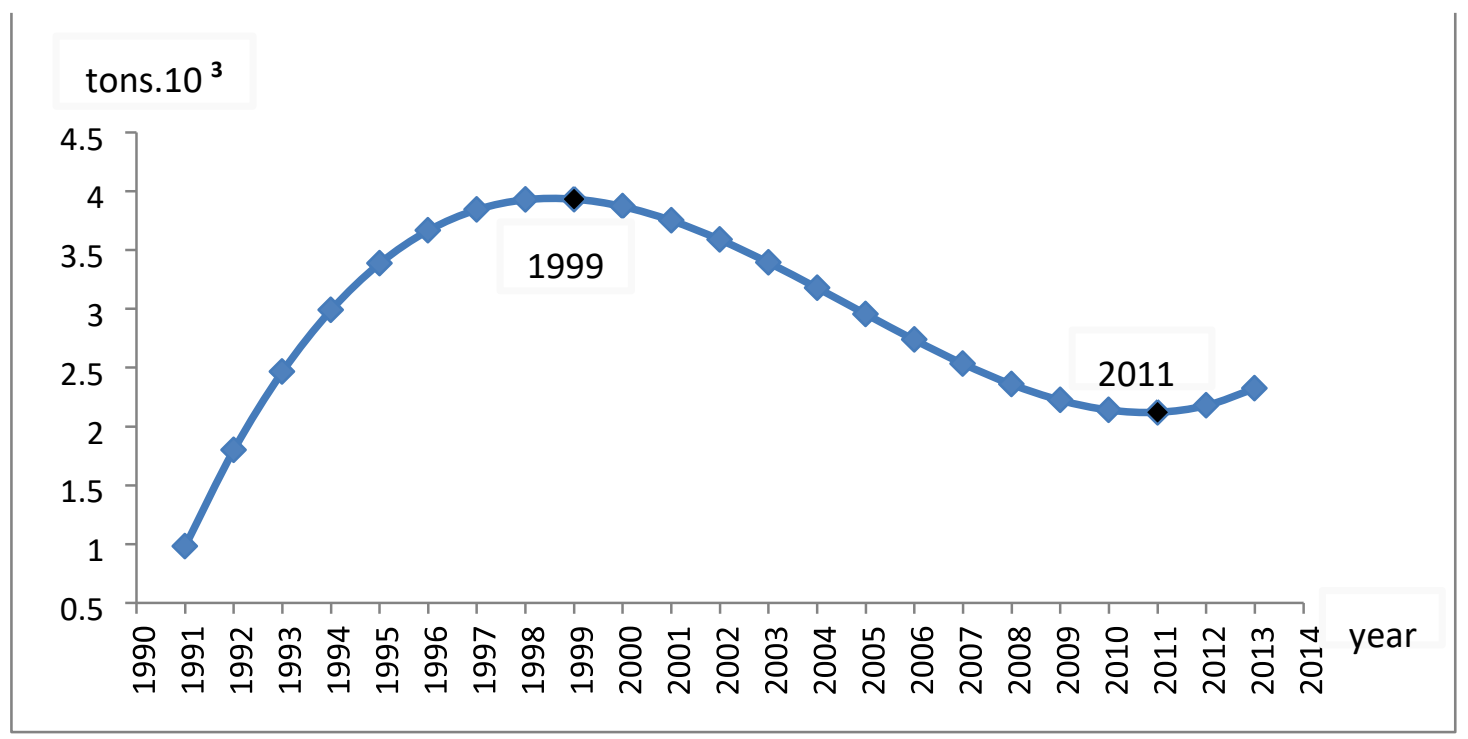

Figure (3): Trend of fish catch in Mariut Lake during (1991-2013)

2.3. Fish catch in Burullus Lake : Best trend of fish catch in Burullus Lake approximated with parabolic curve (Quadratic) during the period of study, Figure (4). Table (3) shows a growing trend with decreasing increments. It reaches a maximum in 2001, due to the fact that it was charcterised by a relatively low variation (c.v. $\%=7.2 \%$ ) - table (2), as thus:

$\hat{\mathrm{Y}} 3=50.774+1.174 \mathrm{X}-0.054 \mathrm{X}^{2}$
$(21.639)^{* *}$
$(2.605) * *(-2.967) * * \mathrm{R}=0.693$
$\mathrm{R}^{2}=0.480$
$\mathrm{F}=5.853 * *$

\section{Where:}

$\hat{\mathbf{Y}} \mathbf{3}$ : Estimated fish catch (thousand tons).

$\mathbf{X}$ : Time throw the period (1991-2013). 
$(\ldots)^{* *}:$ T test is significant approximately 0.01 .

Maximum of a parabola.

$\mathrm{X}_{\text {maximum }}=\mathrm{b} / 2 \mathrm{c}=1.174 /(2 * 0.054)=11$, in 2001.

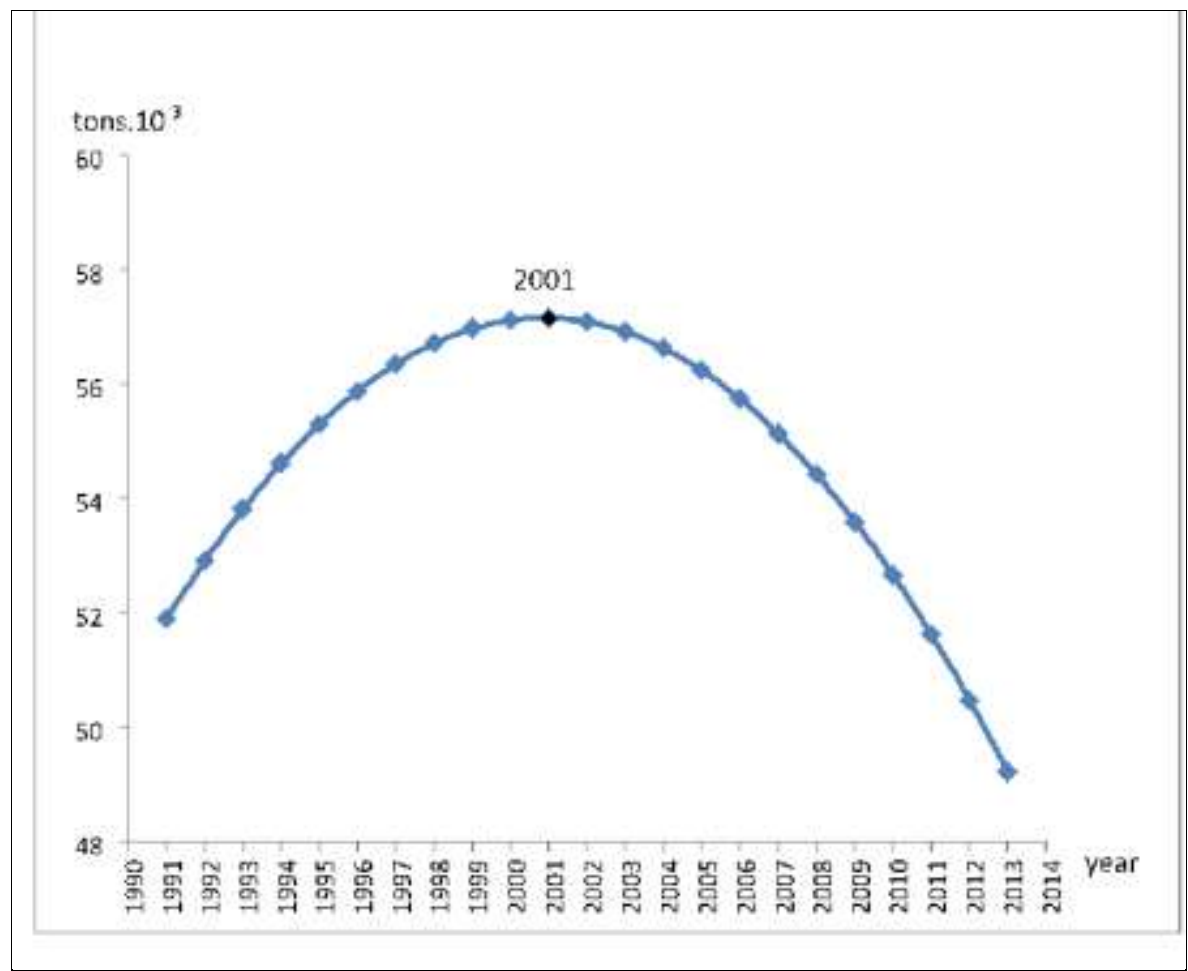

Figure (4): Trend of fish catch in Burullus lake during (1991-2013)

Table (3): Annual Marginal increments* of fish catch in Burullus\& Edku lakes during (1991-2013).

\begin{tabular}{c|c|c}
\hline Year & Burullus lake & Edku lake \\
\hline 1991 & +2.0 & +4.0 \\
1992 & +1.8 & +3.5 \\
1993 & +1.6 & +3.0 \\
1994 & +1.4 & +2.5 \\
1995 & +1.2 & +2.0 \\
1996 & +1.0 & +1.4 \\
1997 & +0.8 & +0.9 \\
1998 & +0.6 & +0.3 \\
1999 & +0.4 & 0 \\
2000 & +0.2 & -0.7 \\
2001 & 0 & -1.3 \\
2002 & -0.2 & -1.8 \\
2003 & -0.4 & -2.4 \\
2004 & -0.6 & -2.9 \\
2005 & -0.8 & -3.4 \\
2006 & -1.0 & -4.0 \\
2007 & -1.2 & -4.5
\end{tabular}




\begin{tabular}{l|l|l}
2008 & -1.4 & -5.1 \\
2009 & -1.6 & -5.6 \\
2010 & -1.8 & -6.2 \\
2011 & -2.0 & -6.7 \\
2012 & -2.2 & -7.2 \\
2013 & -2.4 & -7.8 \\
\hline
\end{tabular}

$*=(2 \mathrm{cx} \pm \mathrm{b}) / \mathrm{Y} * 100$. Calculated from $\hat{\mathrm{Y}} 3, \hat{\mathrm{Y}} 4$ estimated equations.

2.4. Fish catch in Edku Lake: Best fish catch of Edku Lake trend approximated with parabolic curve (Quadratic) during the period of study, Figure (5). It was characterized by growing trend with decreasing increments, table (3). A maximum value took place in 1999:

$\hat{\mathbf{Y}} 4=8.089+0.397 X-0.023 X^{2}(12.324) * * \quad(3.147)^{* *}(-4.492)^{* *} \mathbf{R}=0.835 \quad \mathbf{R}^{2}=0.697 \quad \mathbf{F}=22.950 * *$

\section{Where:}

$\hat{\mathbf{Y}} 4$ : Estimated fish catch (thousand tons).

$\mathbf{X}$ : Time throw the period (1991-2013).

$(\ldots)^{* *}$ : T test is significant approximately 0.01 .

\section{Maximum of a parabola.}

$\mathrm{X}_{\text {maximum }}=\mathrm{b} / 2 \mathrm{c}=0.397 /(2 * 0.023)=9$, in 1999 .

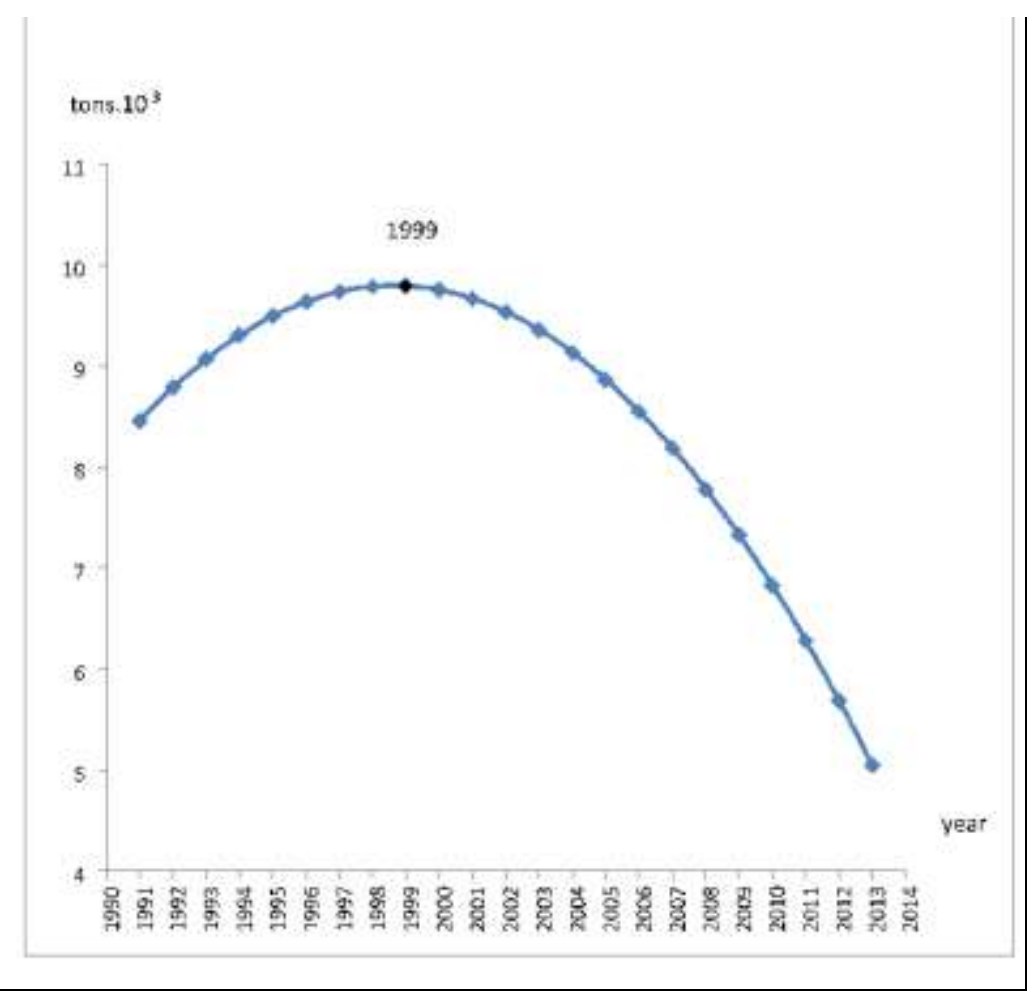

Figure (5): Trend of fish catch in Edku Lake during (1991-2013) 
From the above, for Edku Lake, it is clear that: it can be predicted that the fish catch will continue to decrease due to high relatively variability (c.v. $\%=19 \%$ ), table (2).

It could be concluded from the previous: Although the relative stability of fish catch in Burullus and Edku Lakes comparing to Manzala and Mariut Lakes (according to c.v.\% values), the prediction future fish catches from these lakes will continue increasing in Manzala and Mariut Lakes and decreasing in Burullus and Edku (according to the best estimated fish catch trends). This reflects the weakness of fish production of these lakes.

\section{Eutrophication of Northern Delta Lakes}

3.1. Lake Eutrophication : Eutrophication refers to the food or nutrient content level in the water body. Eutrophic lake is a very shallow pond, and full of rooted aquatic plants. That may or may not have high levels of nutrients. Because Now trophic state not only refers to the nutrient status of the water, but also to the biological production that occurs in the water and to morphological characteristics of the lake basin itself ${ }^{8}$.

All lake fisheries in the world are carried out in three main trophic types of the water bodies. These types are oligotrophic, mesotrophic and eutrophic. They are determined by the basic rules governing the natural environment of the lake fisheries. An ecological pyramid consists of the fact that the production on higher trophic level is determined by production on lower levels. The lowest level, the so-called first trophic level, represents primary production of the system. The highest level is represented by predators of the higher order ${ }^{9}$.

In water bodies, the first trophic level is represented by phytoplankton, the last by predatory fishes. It is clear that pyramid of biomass showing a sharp decrease at higher trophic level - figure (5).

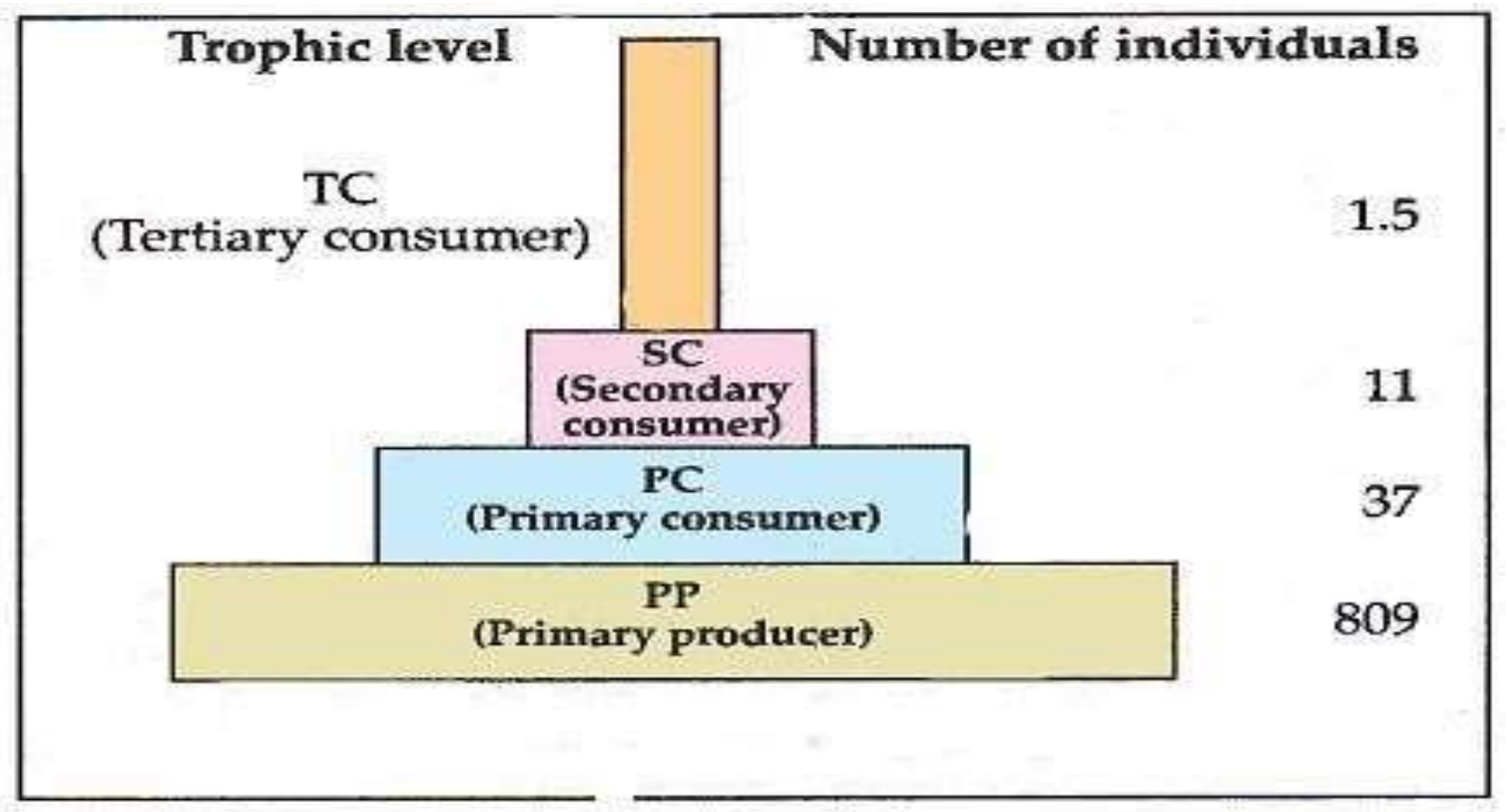

Figure (5): Ecological pyramid, number express biomass values.

Resources of energy in the first trophic level consist of carbon dioxide, water, chlorophyll; nutrients and energy of sunlight are converted to living protoplast in plant cells, with accessary production of oxygen. So on case of fishery there are interest in the production of the highest trophic level, figure (6). 


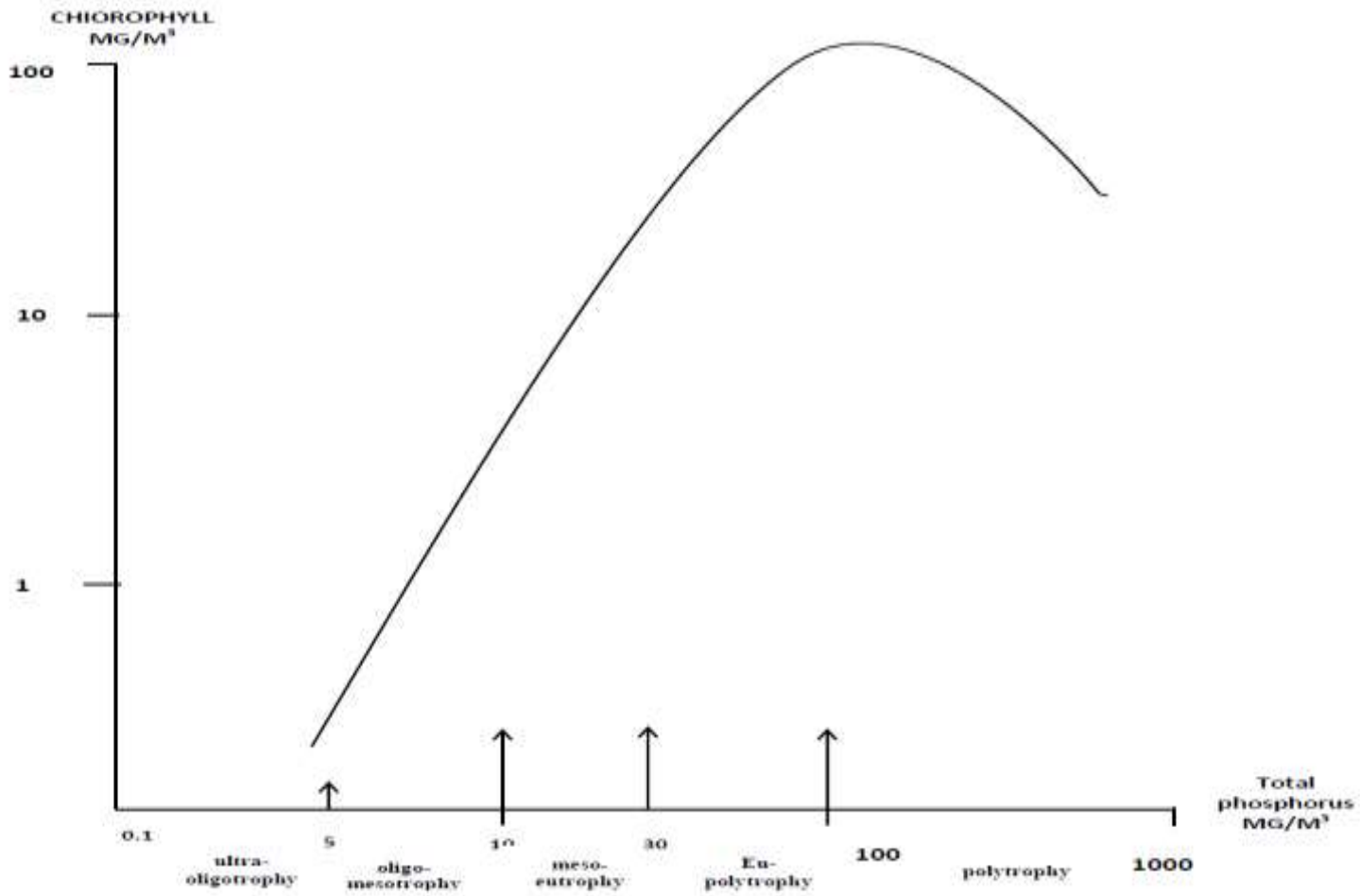

Figure (6): Tropic succession of lakes, Relationship between phosphorus and primary production.

\section{Oligotrophic Lakes are characterized by:}

a. Steep shoreline and bottom gradient.

b. Low nutrient enrichment.

c. Little planktonic growth.

d. Few aquatic plants.

e. Sand or rock along most of shoreline.

f. Coldwater fishery.

g. High dissolved oxygen content.

\section{Mesotrophic Lakes are charcterised by:}

a. Moderate nutrient enrichment.

b. Moderate planktonic growth.

c. Some sediment accumulation over most of lakes bottom.

d. Usually supports warm water fisheries.

\section{Eutrophic Lakes are charcterised by:}

a. High nutrient enrichment.

b. Much planktonic growth (high productivity). 
c. Extensive aquatic plant beds.

d. Much sediment accumulation on bottom.

e. Low dissolved oxygen on bottom.

f. Only warm water fish species.

Separate type is represented by polytrophic water body, which usually includes shallow lakes of the pond type, as also deeper lakes, highly eutrophic or polluted. This water bodes represents as transitory stage between high eutrophic and total destruction of the natural ecosystem, and are frequently unsuitable for fish production, figure 7 (El-Caryony, 1986 and Environmental fact sheet, 2010).
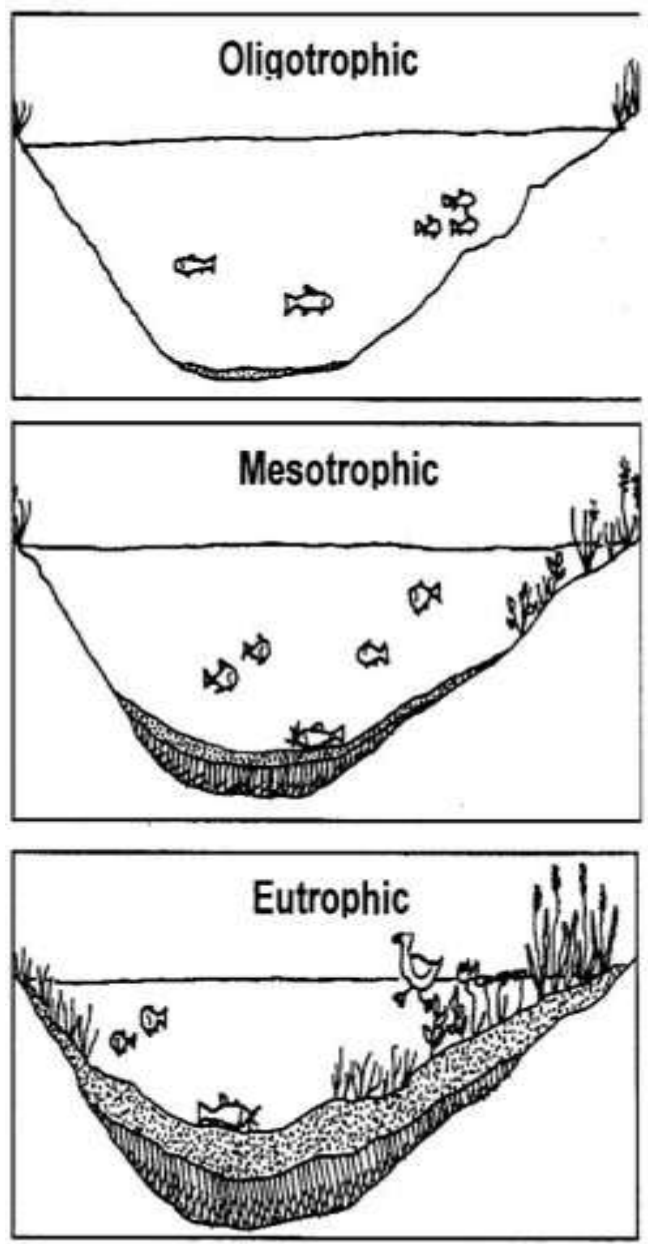

Figure (7): Trophic categories of Lakes.

3.2. The location of Northern Delta Lakes in the classification of Lake Trophy according to Vollenweider, 1968: The total phosphorus amount in water of Egyptian Northern Delta Lakes are about $316.83 \mathrm{mg} / \mathrm{m}^{3}, 639.05 \mathrm{mg} / \mathrm{m}^{3}, 541.91 \mathrm{mg} / \mathrm{m}^{3}$ and $693.05 \mathrm{mg} / \mathrm{m}^{3}$ in Manzala, Mariut, Burullus and Edku lakes. Consequently comparing these amounts of phosphorus with Vollenweider's classification, it become quite obvious that all lakes under study in the $5^{\text {th }}$ stage of Vollenweider model, which means that all these lakes are polluted, table (4).

Eutrophication of Egyptian Northern Delta Lakes in the recent years is caused by the influence of different pollutants which continuously enter in these lakes, table (5) such as: 
1. The large amount of incoming allochthonous -The sediment or rock that originated at a distance from its present position - and waste water into the lakes like domestic, agricultural, and industrial sewages, which reached about 4000, 4380, 2555 and 20.4 million $\mathrm{m}^{3} /$ year in Manzala, Mariut, Burullus and Edku lakes respectively.

2. Vast amounts of autochthonous matter produced in the lakes from decomposition of massive phytoplankton blooms, (El-Caryony, 1986).

Table (4): Comparing the classification of Lake Trophy according to Vollenweider 1968, with the current total phosphor amount in (2012-2013).

\begin{tabular}{|c|c|c|c|c|}
\hline \multicolumn{2}{|c|}{$\begin{array}{c}\text { Vollenweider classification of Lake } \\
\text { Trophy }\end{array}$} & \multirow{2}{*}{ The results } \\
\cline { 1 - 3 } Trophic type & Trophic type & lake & $\left(\mathbf{m g} / \mathbf{m}^{3}\right)$ & \\
\hline Ultra- oligotrophic & $<5$ & Manzala Mariut & 316.83 & All lakes in the stage of \\
Oligo- mesotrophic & $5-10$ & Burullus Edku & 639.05 & polytrophic \\
Meso- eutrophic & $10-30$ & & 541.91 & \\
Eu- polytrophic & $30-100$ & & 693.05 & \\
\hline Polytrophic & $>100$ & - & - & \\
\hline
\end{tabular}

Source: collected from: 1.El- karyony,I.A.(1986), Bioeconomic Analysis of Fishery Management in Lake Mariut ,Ph. D, Academy of Agriculture And Technology, Olsztyn, Poland. ; 2.The Ministry of State for Environmental Affairs, Seasonal report (2012-2013) of Environmental monitoring program for northern lakes, Egypt.

Constituents commonly present in sewage and in industrial wastes from toxic mixtures are: iron, manganese, copper, zinc, chrome, nickel, cadmium, lead and mercury. The amounts of these pollutants vary from lake to another, table (5).

The influence of accumulation toxicants in a water body and aquatic organism in these lakes could be:

- Inhibition of detoxifying enzymes which can influence the uptake or loss of the xenobiotics (substances that are foreign to the body or to an ecological system).

- Action upon biological surface thereby affecting the permeability of membranes to other toxicants present.

- Physiological effects, such as increasing the flow of blood through the gills.

- External factors, such as forming of complexes.

There seem to be some possibility of slowing down or inhibiting this decrease and oscillated fish catch by proper fishery management, which can be applied easily in Burullus and Edku lakes compared to Manzala and Mariut lakes. Because of the lower value of coefficient of variation, the higher possibility to direct investment with low risks, table (2). Hence it can be predicted that, if no proper action is taken to improve the environmental condition in these lakes, fish production will continue to decrease. 
Table (5): The amount of incoming waste water into the lake (Domestic, Agricultural, and Industrial sewages), and the amount of the most important pollutants of Northern Delta Lakes of Egypt in (2012-2013).

\begin{tabular}{|c|c|c|c|c|c|c|c|c|c|c|c|c|}
\hline \multirow[b]{2}{*}{ lake } & \multirow{2}{*}{$\begin{array}{c}\text { The amount } \\
\text { of } \\
\text { incoming } \\
\text { waste } \\
\text { water } \\
\text { into the lake } \\
\text { (million } \\
\text { m³/year) }^{3} \text {. }\end{array}$} & \multirow[b]{2}{*}{$\begin{array}{c}\text { The } \\
\text { range of } \\
\text { Water } \\
\text { level or } \\
\text { lake } \\
\text { depth } \\
\text { (m) }\end{array}$} & \multicolumn{10}{|c|}{$\begin{array}{l}\text { The amount of the most important pollutant } \\
\qquad\left(\mathrm{mg} / \mathrm{m}^{3}\right)\end{array}$} \\
\hline & & & Iron & Manganese & Copper & Zinc & Chrome & Nickel & Cadmium & Lead & Mercury & $\begin{array}{l}\text { The } \\
\text { total }\end{array}$ \\
\hline Manzala & 4000 & 1-1.5 & 101.3 & 22.6 & 23.5 & 43.1 & 6.1 & 6.3 & 0.9 & 29.8 & 0.1 & 233.7 \\
\hline Mariut & 4380 & $0.3-6.3$ & 99.3 & 34.3 & 18.0 & 62.8 & 6.5 & 7.1 & 1.2 & 25.1 & 0.2 & 254.5 \\
\hline Burullus & 2555 & 0.4-2.0 & 151.7 & 13.6 & 26.4 & 72.4 & 7.4 & 8.2 & 1.9 & 38.5 & 0.2 & 320.3 \\
\hline Edku & 20.4 & $0.3-4.2$ & 84.9 & 13.6 & 16.0 & 46.6 & 6.3 & 6.4 & 1.5 & 18.9 & 0.1 & 194.3 \\
\hline
\end{tabular}

\section{Source: collected from}

1- International information network.

2- The Ministry of State for Environmental Affairs, Seasonal report (2012-2013) of Environmental monitoring program for northern lakes, Egypt. 


\section{CONCLUSION}

Northern Delta Lakes in Egypt are highly polluted lakes. It can be classified as a transitory stage between high eutrophic and total destruction. Phosphorus content in these lakes is high. These lakes are more or less similar to each other as regards of their morphometry, hydro-chemical conditions, climatic conditions etc. So their productive potential should also be more or less similar. However, the development of fishery management in these lakes should apply the management program focus on the fish exploitation and proper policy toward lake fisheries.

\section{REFERENCES}

1. R.A. Vollenweider, Scientific fundamentals of the eutrophication of lakes and flowing waters with particular reference to nitrogen and phosphorus as factors in eutrophication. OECD, Directorate for Sci. Affaira, 1968, DAS/CST/68-27: 1-182.

2. T. W. Anderson, The statistical analysis of time series, John Willy and Sons Inc, New York, London, Sidney and Toronto,1971.

3. I.Sh. Maiyza, An Economic study of Fish Production In Alexandria Mediterranean Sea Fisheries, Ph.D. Thesis, Faculty of Agriculture, Alexandria University ,Egypt,2015, p:16.

4. The Central Agency for Public Mobilization and Statistics (CAPMAS). Year-book of fishery statistics (1995-1999),Cairo, Egypt,2016.

5. The Genreal Authority for Fish Resources Development (GAFRD). Year-book of fishery statistics (2000-2013), Cairo, Egypt,2016.

6. The Ministry of State for Environmental Affairs, Seasonal report of Environmental monitoring program for northern lakes, Egypt, 2012-2013

7. Water Quality Assessment, A Guide to Use of Biota, Sediment and Water in Environmental Monitoring- Second Edition, Chapter 7 ,United Nations, Eductional, Scientific and Culture Organization (UNESCO), World Health Organization (WHO), United Nations Environment Programme (UNEP), 1996.

8. Environmental Fact Sheet, Lake Eutrophication, New Hampshire department of Environmental Services, International information network,2012.

9. El-Caryony, Bioeconomic Analysis of Fishery Management in Lake Maruit, (Egypt). Ph.D. Thesis, Academy of Agriculture and Technology, Olsztyn, Poland, 1986, 1-4, 52-53.

\section{* Corresponding Author: Maiyza, Sh. I.}

National Institute of Oceanography and Fisheries (IOF),Egypt;

Shemo_iam@yahoo.com, karyony1948@yahoo.com 